JMK: JURNAL MEDIA KESEHATAN

P-ISSN : 1979-5750

E-ISSN: 2654-5705

\title{
Tingkat Kepatuhan Penggunaan Masker dan Hand sanitizer Mahasiswa Universitas Universitas 17 Agustus 1945 Jakarta Selama Pandemi Covid-19
}

\author{
Dina Marsella Br. Ginting ${ }^{1}$, Ekajayanti Kining ${ }^{2)}$, dan Sogandi ${ }^{1)}$ \\ ${ }^{1}$ Program Studi Farmasi, Fakultas Farmasi,Universitas 17 Agustus 1945, Jakarta 14350 \\ ${ }^{2}$ Program Studi Biokewirausahaan, Universitas Muhammadiyah Enrekang, Enrekang 91712 \\ E-mail: ekakining@unimen.ac.id
}

\begin{abstract}
Problems: Wearing mask and hand hygiene were the main choices in an effort to reduce the transmission of Covid-19 when doing outdoor activity. Various efforts have been made by the government in disseminating this recommendation to all levels of society including college students. College students as a layer with a high level of education were expected to obey the appeal given, including students of the University of 17 August 1945 Jakarta. This study aimed: to determine the compliance college students at the University of 17 August 1945 of wearing mask and hand sanitizer during the Covid-19 pandemic. Research method: The method was used descriptive quantitative with a cross-sectional study design. Data collection used an online questionnaire containing closed questions. A total of 309 people participated in this survey and answered the use of masks and hand sanitizers. Results: College students used masks and hand sanitizers during the Covid-19 pandemic. The compliance rate for the use of masks was $68.6 \%$ and hand sanitizer $78.3 \%$ during the Covid-19 pandemic. Men werw more obedient to using mask $73.6 \%$ and hand sanitizer $84.3 \%$ compared to women using mask $64.5 \%$ and hand sanitizer $73.4 \%$.
\end{abstract}

Keywords: Covid-19, Hand sanitizer, Compliance, Mask, Pandemic

\begin{abstract}
ABSTRAK
Latar Belakang: Penggunaan masker dan menjaga kebersihan tangan menjadi pilihan utama dalam usaha penurunan penularan Covid-19 saat berkegiatan di luar rumah. Berbagai upaya dilakukan pemerintah dalam sosialisasi anjuran ini kepada seluruh lapisan masyarakat termasuk mahasiswa. Mahasiswa sebagai lapisan dengan tingkat pendidikan yang tinggi diharapkan memiliki kepatuhan terhadap himbauan yang diberikan termasuk mahasiswa Universitas 17 Agustus 1945 Jakarta. Tujuan: Penelitian ini bertujuan mengetahui gambaran kepatuhan penggunaan masker dan hand sanitizer mahasiswa di Universitas 17 Agustus 1945 saat pandemi Covid-19. Metode: Metode pengumpulan data menggunakan kuesioner daring yang berisi pertanyaan tertutup. Total 309 orang berpartisipasi dalam survey ini dan menjawab penggunaan masker dan hand sanitizer. Hasil: Mahasiswa Universitas 17 Agustus menggunakan masker dan hand sanitizer selama pandemi Covid-19. Tingkat kepatuhan penggunaan masker 68,6\% dan hand sanitizer 78,3\% selama pandemi Covid-19. Laki-laki lebih patuh menggunakan masker 73,6\% dan hand sanitizer 84,3\% dibandingkan dengan perempuan menggunakan masker $64,5 \%$ dan hand sanitizer $73,4 \%$.
\end{abstract}

Kata kunci: Covid-19, Hand sanitizer, Kepatuhan, Masker, Pandemi 


\section{PENDAHULUAN}

Pada bulan Desember 2019, kasus virus Corona muncul dan menyerang manusia pertama kali di provinsi Wuhan, China (Huang et al., 2020; Z and JM, 2020). Awal kemunculannya diduga merupakan penyakit pneumonia, dengan gejala serupa sakit flu pada umumnya (Ren et al., 2020). Organisasi Kesehatan Dunia (WHO) mencirikan penyakit ini sebagai pandemi pada 11 Maret 2020. Pertama kali dilaporkan Covid-19 di Indonesia pada tanggal 2 Maret 2020 sejumlah 2 kasus. Pada 31 Maret 2020 terkonfirmasi 2.528 jumlah kasus dan 136 kasus kematian akibat Covid-19 (Kemenkes RI, 2020). Hingga kini, telah menyebar ke semua benua selain Antartika (Singhal, 2020)

Penggunaan masker merupakan bagian dari rangkaian komprehensif langkah pencegahan dan pengendalian yang dapat membatasi penyebaran penyakit-penyakit virus saluran pernapasan tertentu, termasuk Covid-19 (W H O, 2020) Masker melindungi individu dari penyebaran COVID-19 dan mengendalikan sumber penularan melalui droplet (Yudhastuti, 2020). Penggunaan masker di masa pandemic seperti saat ini bukan lagi sebatas kebutuhan, tapi sudah menjadi kewajiban.

Selain dari penggunaan masker, penggunaan hand sanitizer juga salah satu tindakan pencegahan agar tidak terinfeksi Covid-19, terutama bagi mereka yang masih harus beraktivitas di luar rumah. Cairan pembersih tangan antiseptik (hand sanitizer) efektif terhadap penurunan jumlah angka kuman, dan secara deskriptif yang paling efektif adalah alkohol 80\% (World Health Organization (WHO), 2010).

Sebuah penelitian tentang hubungan tingkat pengetahuan dan sikap dengan perilaku penggunaan alat pelindung diri pada mahasiswa Prodi DIII Analisa kesehatan STIKes BTH Tasikmalaya menunjukkan tidak terdapat hubungan antara tingkat pengetahuan dengan perilaku penggunaan alat pelindung. Terdapat hubungan signifikan antara sikap dengan perilaku penggunaan APD. Tingkat pengetahuan tentang APD tidak mempengaruhi perilaku penggunaan APD namun sikap dapat mempengaruhi perilaku penggunaan APD pada mahasiswa. Menurut teori bahwa sikap individu merupakan awal dari terwujudnya tindakan atau perilaku individu (Hamzah, 2020). 
Universitas 17 Agustus merupakan salah satu kampus swasta yang menyediakan kelas karyawan, sehingga sebagian Mahasiswa Universitas 17 Agustus akan beraktifitas diluar rumah selama pandemi Covid-19. Berdasarkan anjuran WHO mengenai penggunaan masker dan hand sanitizer selama pandemic (W H O, 2020). Penulis tertarik melakukan penelitian pada mahasiswa tentang Tingkat Kepatuhan Penggunaan Masker dan Hand sanitizer Mahasiswa Universitas 17 Agustus 1945 Jakarta Selama Pandemi Covid-19.

\section{METODE PENELITIAN}

Penelitian ini menggunakan salah satu jenis metode dari jenis penelitian deskriptif yaitu metode survei. Survei merupakan penelitian dengan mengumpulkan informasi dari suatu sampel dengan menanyakannya melalui angket atau wawancara untuk menggambarkan berbagai aspek dari populasi.

Dalam pengolahan data, peneliti menggunakan teknik analisis data statistik deskriptif. Teknik ini digunakan peneliti karena pengumpulan data dilakukan dengan cara penyebaran kuesioner dan cara pengolahannya dengan perhitungan presentase. Populasi pada penelitian ini yaitu Mahasiswa Universitas 17 Agustus 1945 Jakarta dengan jumlah 1.358 orang. Pengambilan sampel dilakukan dengan cara Random Sampling yang merupakan teknik pengambilan sampel dimana diberi kesempatan yang sama untuk dipilih sebagai anggota sampel. Teknik simpel random sampling memungkinkan setiap unit sampling sebagai unsur populasi memperoleh peluang yang sama untuk menjadi sampel. Perhitungan jumlah sampel penelitian ini menggunakan rumus slovin. Adapun kriteria inklusi yaitu mahasiswa aktif S1 Universitas 17 Agustus 1945 Jakarta yang berada di Jakarta selama pandemi Covid-19 maka didapati besar sampel sebanyak 309 orang.

Teknik pengumpulan data yang dilakukan pada penelitian ini yaitu dengan mempersiapkan angket yang akan disebar, dalam penelitian ini adalah Google Form (https://docs.google.com/forms/d/e/1FAIpQLSc3Gh1rnzGwyn5kXKqg5X6bBalZAv3NytwF AkjahZcYEeu9Q/viewform? usp=sf_link). Setelah itu membuat pertanyaan - pertanyaan dan pilihan jawaban yang sudah disiapkan. 
Dalam analisis data dilakukan dengan analisis univariat. Analisis univariat adalah suatu teknik analisis data terhadap satu variabel secara mandiri, tiap variabel dianalisis tanpa dikaitkan dengan variabel lainnya. Analisis univariat bisa juga disebut analisis deskriptif atau statistik deskriptif yang bertujuan menggambarkan kondisi fenomena yang dikaji. Analisis univariat merupakan metode analisis yang paling mendasar terhadap suatu data. Model analisis univariat dapat berupa menampilkan angka hasil pengukuran, ukuran tendensi sentral, ukuran dispersi/ deviasi/ variability, penyajian data ataupun kemiringan data (Canova, Cortinovis and Ambrogi, 2017).

\section{HASIL DAN PEMBAHASAN}

Hasil pengumpulan data yang dilakukan pada mahasiswa aktif S1 Universitas 17 Agustus 1945 Jakarta, diperoleh sebanyak 309 responden. Analisa gambaran jenis kelamain responden sebanyak 140 responden $(45,3 \%)$ laki-laki, 169 responden $(54,7 \%)$ perempuan. Hasil dapat dilihat pada tabel 1 .

Tabel 1. Distribusi karakteristik responden berdasarkan jenis kelamin

\begin{tabular}{lll}
\hline Jenis Kelamin & Frekuensi (n) & Persen (\%) \\
\hline Laki-laki & 140 & 45.3 \\
Perempuan & 169 & 54.7 \\
Total & 309 & 100.0 \\
\hline
\end{tabular}

Hasil tingkat kepatuhan mahasiswa Universitas 17 Agustus 1945 di Jakarta terhadapat himbauan penggunan masker dan hand sanitizer saat berkegiatan diluar rumah selama masa pandemi Covid-19 dapat dilihat pada tabel 2. 
Tabel 2. Kepatuhan mahasiswa Universitas 17 Agustus 1945 Jakarta menggunaan Masker dan Hand sanitizer $(\mathrm{N}=309)$

\begin{tabular}{|c|c|c|c|}
\hline No & PERTANYAAN & YA & TIDAK \\
\hline 1 & $\begin{array}{l}\text { Apakah Anda menggunakan masker saat berkegiatan diluar rumah } \\
\text { selama pandemi? }\end{array}$ & $276(89,3 \%)$ & $33(10,7 \%)$ \\
\hline 2 & $\begin{array}{l}\text { Apakah Anda selalu menggunakan masker selama di transportasi } \\
\text { umum? }\end{array}$ & $281(90,9 \%)$ & $28(9,1 \%)$ \\
\hline 3 & $\begin{array}{l}\text { Apakah Anda selalu menggunakan masker saat bertemu dengan orang } \\
\text { lain (berbeda tempat tinggal) diluar rumah? }\end{array}$ & $275(90 \%)$ & $34(10 \%)$ \\
\hline 4 & $\begin{array}{l}\text { Apakah Anda selalu menggunakan masker saat keluar rumah untuk } \\
\text { membeli kebutuhan sehari-hari? }\end{array}$ & $279(90,3 \%)$ & $30(9,7 \%)$ \\
\hline 5 & $\begin{array}{l}\text { Apakah Anda selalu menggunakan masker saat ketempat ibadah selama } \\
\text { pandemi? }\end{array}$ & $278(89,9 \%)$ & $31(10,1 \%)$ \\
\hline 6 & $\begin{array}{l}\text { Apakah Anda selalu menggunakan hand sanitizer setelah menyentuh } \\
\text { suatu benda atau permukaan yang digunakan secara bersamaan saat } \\
\text { berkegiatan diluar rumah selama pandemi? }\end{array}$ & $291(94,1 \%)$ & $18(5,9 \%)$ \\
\hline 7 & $\begin{array}{l}\text { Apakah Anda selalu menggunakan hand sanitizer setelah melepaskan } \\
\text { masker? }\end{array}$ & $286(92,5 \%)$ & $23(7,5 \%)$ \\
\hline 8 & $\begin{array}{l}\text { Apakah Anda selalu menggunakan hand sanitizer setelah melakukan } \\
\text { transaksi pembayaran? }\end{array}$ & $279(90,3 \%)$ & $30(9,7 \%)$ \\
\hline 9 & $\begin{array}{l}\text { Apakah Anda selalu menggunakan hand sanitizer setelah menggunakan } \\
\text { toilet umum? }\end{array}$ & $274(88,7 \%)$ & $35(11,3 \%)$ \\
\hline 10 & Apakah Anda selalu menggunakan hand sanitizer sebelum makan? & $278(89,9 \%)$ & $31(10,1 \%)$ \\
\hline
\end{tabular}

\section{Penilaian Tingkat Kepatuhan Penggunaan Masker}

Hasil penelitian kepatuhan penggunaan masker oleh Mahasiswa Universitas 17 Agustus 1945 Jakarta selama pandemi Covid-19 sebanyak 212 (68,6\%) responden yang patuh dan sebanyak 97 (31,4\%) responden yang tidak patuh. Penilaian tingkat kepatuhan responden ketika menjawab semua pertanyaan dengan jawaban "Ya". Hasil penelitian ini sejalan dengan hasil penelitian tentang penggunaan masker wajah selama pandemi Covid-19 di Universitas Medical Wroclaw Polandia menyatakan sebanyak 60,4\% responden menggunakan masker wajah (Matusiak et al., 2020). 
Munculnya Covid-19 menyebabkan semua orang harus menggunakan masker saat berkegiatan diluar rumah. Penggunaan masker wajah dapat berfungsi sebagai kontrol sumber dengan mencegah penyebaran tetesan saat berbicara, bersin, dan batuk (Hui et al., 2012), serta mengurangi risiko pencemaran lingkungan oleh SARS-CoV-2 (W H O, 2020). Manfaat utama penggunaan masker termasuk dalam membatasi penyebaran virus dari orang yang tahu atau tidak tahu bahwa mereka menularkan ke orang lain.

Bagi Sebagian mahasiswa Universitas 17 Agustus 1945 Jakarta, penggunaan masker belum menjadi kebiasaan. Hal tersebut mengakibatkan masih adanya mahasiswa yang tidak menggunakan masker saat berkegiatan diluar rumah. Selain itu kesulitan dalam berkomunikasi juga menjadi penyebab ketidakpatuhan dalam menggunakan masker (Matusiak et al., 2020). Beberapa responden mengatakan bahwa meskipun ada perlindungan yang diberikan oleh masker wajah, tetapi juga dapat menjadi penyebab beberapa efek samping, termasuk kesulitan bernapas, bicara cadel, pemanasan /berkeringat dan gatal (Szepietowski et al., 2020). Hal tersebut terjadi pada tenaga kesehatan di Singapura yang bekerja di area berisiko tinggi diharuskan memakai alat pelindung diri (APD) seperti masker wajah N95 dan kacamata pelindung saat merawat pasien. Berdasarkan data hasil penelitian, responden dengan diagnosis sakit kepala yang sudah ada menyatakan "setuju" atau "sangat setuju" bahwa peningkatan penggunaan APD telah memengaruhi pengendalian sakit kepala yang dapat mempengaruhi kinerja pekerjaan mereka (Ong et al., 2020), terutama jika paparan jangka panjang terhadap peralatan tersebut diperlukan selama pandemic (APIC Emergency Preparedness Committee, Public Policy Committee and Regulatory Review Panel, 2009).

Sakit kepala yang timbul dari tekanan yang berkelanjutan pada jaringan lunak perikranial saat mengenakan benda dengan pita atau tali yang ketat di sekitar kepala (misalnya, topi, helm, google yang dikenakan saat berenang atau menyelam, atau perangkat frontal lux) telah dilaporkan pada beberapa penelitian sebelumnya (Rahmani et al., 2017; Olesen, 2018), Ketegangan pada tengkuk leher juga bisa menyebabkan perkembangan nyeri kepala servikogenik atau sakit kepala tipe tegang (tension-type headache) (Barmherzig and Kingston, 2019; Liang et al., 2019). 
Kurangnya sosialisasi dari otoritas kesehatan dan pemerintah juga mempengaruhi sikap dan praktik dalam menanggapi pandemi Covid-19 (Azlan et al., 2020). Jika hanya direkomendasikan dan tidak wajib dapat mempengaruhi kepatuhan penggunaan masker (Matusiak et al., 2020). Selain itu kebanyakan narasumber merasakan tanggung jawab dan komitmen untuk mengikuti langkah-langkah pencegahan, lebih tepatnya, bertujuan untuk menjaga kesehatan orang lain (Honarvar et al., 2020).

Selama pandemi Covid-19 ini terdapat krisis yang jelas dalam ketersediaan perlindungan wajah professional (Wang et al., 2020). Masker medis wajib disediakan untuk tenaga Kesehatan (Setiati and Azwar, 2020). Penggunaan masker medis di masyarakat akan menyebabkan kelangkaan masker bagi petugas Kesehatan (W H O, 2020). Dampak pandemi COVID-19, seperti ketakutan masyarakat akan penyakit, menyebabkan masyarakat berbondong-bondong membeli masker dan bahkan menimbunnya. Hal ini menyebabkan meroketnya harga masker medis.

Kelangkaan masker medis telah menjadi masalah global karena meningkatnya permintaan sebagai tanggapan terhadap Covid-19. Dibeberapa negara salah satunya Kementrian Kesehatan Malaysia bersikukuh memberlakukan peraturan bahwa masker wajah medis hanya boleh dipakai oleh mereka yang menunjukkan gejala Covid-19 atau penyakit serupa (Azlan et al., 2020), untuk memastikan pasokan yang cukup dari alat pelindung diri bagi pekerja medis di garis depan.

\section{Penilaian Tingkat Kepatuhan Penggunaan Hand sanitizer}

Dari hasil penelitian diperoleh data kepatuhan penggunaan hand sanitizer sebanyak $242(78,3 \%)$ responden yang patuh, dan sebanyak $67(21,7 \%)$ responden yang tidak patuh. Hasil penelitian ini hampir sama dengan penelitian tentang Pengetahuan, sikap, dan praktik publik terhadap Covid-19 di Malaysia yang menyatakan responden menjaga kebersihan tangan yang benar dengan sering mencuci tangan dan menggunakan pembersih tangan (Hand sanitizer) sebanyak (87,8\%). Pada penelitian tersebut menyatakan kepatuhan menjaga kebersihan tangan berhubungan dengan pendidikan. Pelajar cenderung mempraktikkan kebersihan tangan yang baik (Canova et al., 2020). 
Covid-19 dapat ditularkan oleh orang yang terinfeksi meskipun tidak ada gejala penyakit. Sementara menjaga kebersihan tangan yang baik adalah metode yang paling penting untuk mencegah penularan virus. Saat ini, handrub atau handsanitzier berbahan dasar alkohol adalah satu-satunya cara yang diketahui untuk secara cepat dan efektif menonaktifkan berbagai mikroorganisme yang berpotensi berbahaya di tangan (World Health Organization (WHO), 2010). Data laboratorium menunjukkan bahwa 60\% etanol dan 70\% isopropanol, bahan aktif dalam pembersih tangan berbasis alcohol, menonaktifkan virus yang secara genetik dan dengan sifat fisik yang mirip dengan 2019nCoV (Alderman, 2020; Thomson and Bullied, 2020).

Dalam hal penggunaan handsanitzier mahasiswa cenderung lebih memilih mencuci tangan dengan sabun dibandingkan dengan handsanitzier setelah menggunakan toilet umum. Karena ketersediaan air yang cukup saat berada di toilet. Selain itu, juga disebabkan adanya kenaikan harga hand sanitizer selama pandemic.

Hubungan kepatuhan penggunaan masker dan hand sanitizer adalah penggunaan hand sanitizer lebih tinggi dibandingkan dengan penggunaan masker. Penggunaan hand sanitizer cenderung lebih mudah digunakan dimana saja dan kapanpun. Namun berbeda dengan penggunaan masker yang belum menjadi norma dalam kehidupan sehari-hari.

Kepatuhan Responden mengguanan Masker dan Hand sanitizer berdasarkan jenis kelamin

Hasil tingkat kepatuhan mahasiswa Universitas 17 Agustus 1945 di Jakarta terhadapat himbauan penggunan masker dan hand sanitizer saat berkegiatan diluar rumah selama masa pandemi Covid-19 berdasarkan jenis kelamin dapat dilihat pada tabel 3 .

Tabel 3. Kepatuhan Responden mengguanan Masker dan Hand sanitizer berdasarkan jenis kelamin

\begin{tabular}{ccc}
\hline Tingkat kepatuhan & Perempuan & Laki-laki \\
\hline Masker & $109(64,3 \%)$ & $103(73,6 \%)$ \\
Handsanitzier & $124(73,4 \%)$ & $118(84,3 \%)$ \\
\hline
\end{tabular}


Berdasarkan data penelitian, terlihat bahwa tingkat kepatuhan penggunaan masker dan hand sanitizer perempuan lebih tinggi dari pada laki-laki, meskipun tidak signifikan. Penelitian ini sejalan dengan penelitian tentang kebersihan tangan, perilaku menggunakan masker dan faktor yang terkait selama pamdemi Covid-19 di sekolah dasar di Wuhan, Cina. Dimana perempuan lebih efektif mencuci tangan dan menggunakan masker (Chen et $a l ., 2020)$. Hal yang sama terjadi di beberapa daerah di Iran. Data menunjukkan bahwa lakilaki memiliki tingkat pengetahuan yang lebih rendah dan memiliki praktik yang lebih tidak tepat tentang berbagai aspek COVID-19 daripada perempuan (Honarvar et al., 2020). Perempuan kurang bersedia untuk mengambil risiko sehingga mengikuti anjuran menjaga kebersihan tangan serta menggunaan masker. Oleh sebab itu, pendidikan yang lebih efektif harus diberikan kepada laki-laki, orang tua, dan mereka yang berpendidikan rendah, terutama di daerah tertinggal (Tavakoli, Vahdat and Keshavarz, 2020).

\section{KESIMPULAN}

Berdasarkan hasil penelitian ini dapat disimpulan bahwa Mahasiswa Universitas 17 Agustus 1945 Jakarta mematuhi aturan menggunakan masker dan hand sanitizer selama pandemi Covid-19 dan tingkat kepatuhan adalah 68,6\% dan 78,3\%. Bagi peneliti selanjutnya disarankan untuk menambah variabel independen maupun dependen yang memiliki kemungkinan pengaruh terhadap Tingakat kepatuhan penggunaan Masker dan Hand sanitizer selama pandemi Covid-19 serta menambah jumlah sampel sehingga penelitian dapat digeneralisasikan.

\section{DAFTAR PUSTAKA}

Alderman, C. (2020) 'COVID-19: Shortages, and Rapid Medication Therapy Trials', The Senior Care Pharmacist, 35(6), pp. 243-246.

Azlan, A. A. et al. (2020) 'Public knowledge, attitudes and practices towards COVID-19: A cross-sectional study in Malaysia', PLoS ONE, 15(5), pp. 1-15. doi: 10.1371/journal.pone.0233668.

APIC Emergency Preparedness Committee, Public Policy Committee and Regulatory 
Review Panel (2009) 'APIC Position Paper: Extending the Use and / or Reusing Respiratory Protection in Healthcare Settings During Disasters', Public Policy, p. 10.

B., H. (2020) 'Gambaran Pengetahuan dan Sikap Mahasiswa Kesehatan tentang Upaya Pencegahan Penyebaran COVID-19', Bali Health Published Journal, 2(1 SE-Articles), pp. 1-12. Available at: http://ejurnal.stikeskesdamudayana.ac.id/index.php/ bhpj/article/view/199.

Barmherzig, R. and Kingston, W. (2019) 'Occipital Neuralgia and Cervicogenic Headache: Diagnosis and Management', Current Neurology and Neuroscience Reports, 19(5), pp. 1-8. doi: 10.1007/s11910-019-0937-8.

Canova, S. et al. (2020) 'Description of Handwashing Nurse With The Use of Hand Sanitizer at The Time of Infusion In a Flamboyan Room at RSUD Abdul Wahab Sjahranie Description of Handwashing Nurse With The Use of Hand Sanitizer at The Time of Infusion In a Flamboyan Room at RSUD A', Dermatologic Therapy, 15(April), pp. 1-4. doi: 10.1111/dth.13909.

Canova, S., Cortinovis, D. L. and Ambrogi, F. (2017) 'How to describe univariate data', Journal of Thoracic Disease, 9(6), pp. 1741-1743. doi: 10.21037/jtd.2017.05.80.

Chen, X. et al. (2020) 'Hand hygiene, mask-wearing behaviors and its associated factors during the COVID-19 epidemic: A cross-sectional study among primary school students in Wuhan, China', International Journal of Environmental Research and Public Health, 17(8). doi: 10.3390/ijerph17082893.

Honarvar, B. et al. (2020) 'Knowledge, attitudes, risk perceptions, and practices of adults toward COVID-19: a population and field-based study from Iran', International Journal of Public Health, 65(6), pp. 731-739. doi: 10.1007/s00038-020-01406-2.

Huang, C. et al. (2020) 'Clinical features of patients infected with 2019 novel coronavirus in Wuhan, China', The Lancet, 395(10223), pp. 497-506. doi: 10.1016/S01406736(20)30183-5.

Hui, D. S. et al. (2012) 'Exhaled Air Dispersion during Coughing with and without Wearing a Surgical or N95 Mask', PLoS ONE, 7(12), pp. 1-7. doi: 10.1371/journal.pone.0050845.

Liang, Z. et al. (2019) 'Cervical musculoskeletal impairments in migraine and tension type headache: A systematic review and meta-analysis', Musculoskeletal Science and Practice, 42(February), pp. 67-83. doi: 10.1016/j.msksp.2019.04.007.

Matusiak, Ł. et al. (2020) 'The use of face masks during the COVID-19 pandemic in Poland: A survey study of 2315 young adults', Dermatologic Therapy. doi: 10.1111/dth.13909. 
Olesen, J. (2018) 'Headache Classification Committee of the International Headache Society (IHS) The International Classification of Headache Disorders, 3rd edition', Cephalalgia, 38(1), pp. 1-211. doi: 10.1177/0333102417738202.

Ong, J. J. Y. et al. (2020) 'Headaches Associated With Personal Protective Equipment - A Cross-Sectional Study Among Frontline Healthcare Workers During COVID-19', Headache, 60(5), pp. 864-877. doi: 10.1111/head.13811.

Rahmani, Z. et al. (2017) 'Helmet-induced headache among Danish military personnel', Scandinavian Journal of Public Health, 45(8), pp. 818-823. doi: 10.1177/1403494817731417.

Ren, L. L. et al. (2020) 'Identification of a novel coronavirus causing severe pneumonia in human: a descriptive study', Chinese medical journal, 133(9), pp. 1015-1024. doi: 10.1097/CM9.0000000000000722.

Setiati, S. and Azwar, M. K. (2020) 'COVID-19 and Indonesia.', Acta medica Indonesiana, 52(1), pp. 84-89.

Singhal, T. (2020) 'A Review of Coronavirus Disease-2019 (COVID-19)', Indian Journal of Pediatrics, pp. 281-286. doi: 10.1007/s12098-020-03263-6.

Szepietowski, J. C. et al. (2020) 'Face mask-induced itch: A self-questionnaire study of 2,315 responders during the COVID-19 pandemic', Acta Dermato-Venereologica, 100(10), pp. 1-5. doi: 10.2340/00015555-3536.

Tavakoli, A., Vahdat, K. and Keshavarz, M. (2020) 'Novel Coronavirus Disease 2019 (COVID-19): An Emerging Infectious Disease in the 21st Century', Iranian South Medical Journal, 22(6), pp. 432-450. doi: 10.29252/ismj.22.6.432.

Thomson, E. L. and Bullied, A. R. (2020) 'Production of Ethanol-Based Hand Sanitizer in Breweries During the COVID-19 Crisis', Technical Quarterly, 57(1), pp. 47-52. doi: 10.1094/tq-57-1-0417-01.Suryopratomo, X. 2005. Pendidikan Modern di Lingkup Anak Muda. Jurnal Kesehatan Indonesia, XX (1): 89-99.

Wang, M. W. et al. (2020) 'Mask crisis during the COVID-19 outbreak', European Review for Medical and Pharmacological Sciences, 24(6), pp. 3397-3399. doi: 10.26355/eurrev_202003_20707.

Yudhastuti, R. (2020) 'The use of cloth face maskduring the pandemic period inindonesian people', Kesmas, 15(2), pp. 32-36. doi: 10.21109/KESMAS.V15I2.3945.

Z, W. and JM, M. (2020) 'Characteristics of and important lessons from the coronavirus disease 2019(COVID-19) outbreak in China’, Jama, 2019, p. 10.1001/jama.2020.2648. 
W H O (2020) 'Advice on the use of masks in the context of COVID-19', Who, (April), pp. $1-5$. Available at: https://www.who.int/publications-.

World Health Organization (WHO) (2010) 'Guide to Local Production: WHOrecommended Handrub Formulations Introduction':, Who, (April), p. 9. Available at: https://www.who.int/gpsc/5may/Guide_to_Local_Production.pdf. 